\title{
Corrosion Behavior of Thermal Seamless Carbon Steel Boiler Pipes
}

\author{
Jamal Nayief Sultan ${ }^{1 *}$, Muna Khethier Abbas ${ }^{2}$, Marwa Abd-al Kareem Ibrahim ${ }^{1}$, Emad Toma Karash ${ }^{3}$, Adel M. Ali $^{3}$, \\ Hssein A. Ibrhim ${ }^{3}$ \\ ${ }^{1}$ Power Mechanical Techniques Eng. Dept., Technical Engineering College, Northern Technical University, Mosul 41000, Iraq \\ ${ }^{2}$ Production and Metallurgical Eng. Dept., University of Technology, Baghdad 10071, Iraq \\ ${ }^{3}$ Mechanical Technology Dept., Technical Institute, Northern Technical University, Mosul 41000, Iraq
}

Corresponding Author Email: muna.k.abbass@uotechnology.edu

https://doi.org/10.18280/acsm.450506

Received: 3 October 2021

Accepted: 21 October 2021

\section{Keywords:}

boiler, steel, carbon, pipes, metal, corrosion,

boiler, seamless carbon

\begin{abstract}
The current study was absorbed on corrosion of ASTM A106 grade B -02 seamless carbon steel boiler pipes. Beyond corrosion experiments in corrosive medium with varying $\mathrm{pH}$ values, the weight lost in addition to corrosion rate (m.p.y) values were computed. The weight loss of boiler tube specimens exposed to corrosive liquid was shown to rise as the exposure period of the specimens increased.

The results of the microstructure imaging showed that a de-carburized film of $240 \mu \mathrm{m}$ thickness was shaped on the fireside of the pipe boiler, with ferrite and a few phases of pearlite. On the water lateral side, it was revealed that boiler pipe failure begins with small rust particles that expand to greater sizes and form scales that are displaced from the boiler pipe's surface. On the surfaces of the boiler pipe water side, several pits with crevice corrosion were observed. The corrosion amounts were discovered to decrease when the specimens' exposure time to corrosive environments and hydrogen ion concentration contents increased $(\mathrm{pH})$. The findings of mechanical characteristic values such as hardness, yield strength, and tensile strength revealed that the waterside had higher values than the fireside, while the middle of the pipe had reasonable values.

The findings also demonstrated that at low $\mathrm{pH}$ values, a tiny size of rust was created on the boiler tube specimen surface. However, at high $\mathrm{pH}$ values of corrosive medium, big sizes of corrosion rust were observed on the specimen surfaces.
\end{abstract}

\section{INTRODUCTION}

Boiler pipes failure could be a common prevalence in chemical factories, power plants, paper production plants, sugar production facilities, and every one alternative business that use boilers [1]. Unscheduled shutdowns in coal-fired boiler facilities are mostly caused by boiler pipe failure, which results in output loss. Many causes contribute to boiler pipe failure, including short-term and long-term overheating, corrosive fatiguing, and mechanical overburdening, creep [1, 2].

In order for rust to occur, iron should dissolve and hydrogen must be released in the presence of oxygen or other oxidizing factors. This assumes electrolytic activity, because every iron ion that occurs at one location necessitates the absence of a hydrogen ion at another location, resulting in the creation of gaseous hydrogen. Because of this element's strong solubility and diffusive power, rarely is gaseous of hydrogen observable during rusting procedure. Corrosion is stimulated by compounds that increase the concentration of hydrogen ions, such as acids and acid salts, whereas corrosion is inhibited by substances that raise the hydroxyl ion concentration [3]. Internal corrosion of boiler pressure components can be classified into types: corrosion due to oxygen, corrosion due to steam, and corrosion with scale. Corrosion due to steam occurs when a metal with a surface temperature greater than 400 degrees Celsius comes into contact with steam and forms a $\mathrm{Fe}_{3} \mathrm{O}_{4}$ coating. The second problem is oxygen corrosion.
The feed water of boiler as well as oxygen in the corrosion caused by electrochemical of the cathode polarization, etching speed of electrochemical, and as temperature increased, the corrosion is blocked. Techniques include using a feed water deaerator to reduce water content and controlling the water speed in the coal economizer tubes to keep air bubbles from being caught in the pipe wall. Electrochemical corrosion increases at high temperatures; the greater the temperature, the more strongly alkaline the metal degradation [4].

Stainless steels, steel and alloys that resists high temperature are the most common materials used in boiler components. In a power plant, boiler pipe failure is a typical occurrence. It is critical to investigate the causes of a boiler pipe failure in order to prevent future pipe failures. Identifying the right failure mechanism frequently aids in ensuring the equipment's integrity. Pitting, stress corrosion cracking, stress rupture, creep, erosion, and thermal fatigue are all causes of boiler tube failure. Stress corrosion and pitting cracking, are all causes of boiler tube failure [5]. It was discovered that fire side corrosion can be found on the heat exchangers surface in gas fired spot water heaters. Durability tests were carried out on five gas fired water heaters that differed in terms of input heat and coating for heat exchangers for a period of 2000 cycles.

Corrosion of fire side can be found on the heat exchangers surface of water heaters working by gas fired. Tests for durability were carried out on a total of five gas-powered water heaters that differed in relation of temperature exchanger 
coating with input heat for a period of two thousand cycles.

Several methods were used to inspect corrosion deposits on the heat exchangers' surfaces. The results revealed that the deposit due to corrosion increased in size as the testing period lengthened. The trials showed that when the heat input increased, the corrosion rate reduced [6].

A method for investigating superheater tube failures made with T-22 metal in a boiler that burns coal is highlighted. Visual examination, identifying sampling sites, chemical composition in bulk determination of the primary alloy, optical microstructure examination, hardness evaluation over different locations samples, different failed locations fractographic analysis, were studied for Corrosion products clung to interior surfaces, as well as the failure nature are all the process part were determined. Three superheater tube failures were observed within four months of each other. The tubes were found to have considerable wall weakening. In the inner surface, layer-wise oxidation corrosion was found. Aside from substantial number of cracks virtually cracking of straight lines were discovered in both tubes axial direction. Void formation/de-cohesion of grain boundary near bulging/ cracking showed creep deformation during service utilization. Excessive oxidation corrosion within the inside wall, the failure mechanism was recognized as spheroidizing alloy carbides and of precipitate coarsening, in addition to creep void development at the grain boundary leading to intergranular cracking flow towards regions covered with thick scales [7].

After ten months of low carbon steel, the principal Waste in an ammonia factory heat boiler suffers cap leaking and outer tube breaking. The improper vertical section of the cap that is leaking, which is shorter than the design by $2.4 \mathrm{~mm}$, may produce turbulent flow within the cap and flow accelerating corrosion, as seen by wall weakening and a horseshoe pattern on the inner surface. Such problem was exacerbated with the use of a cap material with a low chromium level of 0.01 percent, Flow of local turbulence may dissolve the cap bottom oxide layer with collect deposited oxide surrounded the tube's perimeter welded junction, indicated by a dense deposit of $\mathrm{Fe}_{3} \mathrm{O}_{4}$. The initial outer layer of tube failure was possible have occurred as a result of an insufficient cooling from the water of the boiler owing to cover leaking, along with a heavy $\mathrm{Fe}_{3} \mathrm{O}_{4}$ coating of scale upon the nail spacer, which generated large temperature rises on the busted tube, resulting a rupture of thin lip [8].

Reheater and superheater of power station boiler pipes failure station using a gas fuel was investigated. The fire side corrosion has been proposed which is the primary cause of boiler tube failure. The tubes were given by an Iranian fossil fuel power station, and optical and electron microscopy studies were conducted on the pipes, with the corrosion products that have formed on their exteriors. The findings revealed a failed tubes thickness was not uniform, implying that fire-side corrosion had occurred on the tubes. Oxide layers interaction with products of combustion on the surface of the tube causes fire-side corrosion, which results in metal loss and, as a result, tube breakage. The tubes corrosion behavior defied conventional beliefs of corrosion in the fire side. As a consequence, the thickness of the tubes in various regions were measured, and critical spots have been determined. Corrosion monitoring probes were installed at such crucial places [9].

A boiler pipe with a high-pressure economizer failure used gas with mazut was investigated. The pipe failure investigation included thickness measurement, and microstructural measurements was explored. Microscopic pictures show that no microscopic transition was identified during service and that the ferrite and pearlite structure remains. Dew point corrosion discovered being the primary cause of the inspected tube's failure when it was out of operation [10].

The boiler tube failure study of three operational boilers at National Fertilizers Limited Naya Nangal was investigated. The frequent occurrence of boiler tube failure provided an impetus to identify the causes of failure and give remedies in the interest of the nation, and the boiler components characteristics of material were investigated. The nondestructive testing pictures were examined in order to discover interior failure and its progression. The mechanical characteristics of boiler tube material were examined at the point of failure, providing important information for preventative maintenance. Remedial procedures and safeguards were implemented in the coal-firing process, water quality, and plant operation [11]

The mechanical behavior of boiler tube material under these settings was examined, as was corrosion in boiler tubes under high temperature conditions. Failure of boiler tubes due to corrosion attack is a common occurrence in the station, resulting in unscheduled plant shutdown. The scales impact and products of corrosion on heat, resulting in greater temperature in subsurface metal, might result in various mechanisms of failure. It appears that the tube ends were not stress relieved during construction, and when these tubes with sufficient residual stresses came into contact with corrosive condensate, a tensile stress interaction and a corrodent occurred, resulting in stress corrosion cracking [12].

An early water wall pipe failure in two thermal power station boilers with same operating parameters but varied in the chemistry of boiler water was investigated. It was shown that both cases involve waterside corrosion. One boiler is undergoing coordinated phosphate treatment, while another is undergoing every volatile therapy (AVT). Corrosion causes were identified, and solutions for their abolition were presented. To determine the likely reasons of failure, oxide scale thickness measurements and micro structural examinations were performed. Finally, it was determined that the high temperature in the tube metal with wall thinning caused by corrosion deposit resulted in early pipe failure boilers operating with phosphate and pitting corrosion in AVT boilers [13].

Alloying elements (Mo, $\mathrm{Cu}$, and $\mathrm{Cr}$ ) have an effect on the low carbon steel corrosion in $\mathrm{CO}_{2}$ settings was explored. Varying Cr concentrations samples ranging between zero and 2 percent in weight with additional 0.5 percent. The specimens displayed a microstructure of pearlitic/ ferritic. $\mathrm{Cu}$ and $\mathrm{Cr}$ addition has a minor favorable effect on corrosion resistance. The corrosion rate of all specimens reduced over time at $\mathrm{pH}$ 6.6 and $80^{\circ} \mathrm{C}$ due to the production of protective $\mathrm{FeCO}_{3}$ [14].

In simulated district heating water, the pipeline corrosion of steel coated with various oxides of iron was examined. The rate of corrosion of pipe steel Was accelerated in potential dynamic polarization experiments when exposed to iron oxide. The iron oxides deposit discovered to raise the pipeline's failure risk, as well as localized corrosion could occur beneath the pipe line section covered with $\mathrm{FeOOH}$ [15].

A review of carbon steel corrosion in sulfuric acid was reported. Carbon steel corrosion mechanism with sulfuric acid, accelerates variables, carbon steel corrosion types, with preventative techniques are discussed. Corrosion of carbon 
steel storage tanks by concentrated sulfuric acid and pipelines was a major problem. When carbon steel comes when exposed to high sulfuric acid, it undergoes a quick acid assault, resulting in the creation of ferrous ions with hydrogen gas, which then create a shield coating of $\mathrm{FeSO}_{4}$ on the surface [16].

The temperature influence on the corrosion product layer of carbon steel exposed to a $\mathrm{CO}_{2}$-containing solution was studied. The corrosion rates were determined using the weight loss technique. The corrosion mechanisms as they relate to temperature were investigated and addressed. The findings revealed that temperature has a significant impact on the corrosion rate of carbon steel [17].

Carbon steel corrosion resistance after heat treatment impact at varying carbon contents was examined. Corrosive media is composed of fifty grams of salt per one hundred Milliliter water and then chemically created and evaluated. To perform the corrosion test, all samples had been submerged within a corrosive solution for half an hour. The effect of corrosion was then examined. The corrosion endurance of the steel improved as the carbon content increased. Similarly replicated samples had been heated to undergo annealing heat treatment, by using isolated furnace, at $850^{\circ} \mathrm{C}$ and 17 minutes duration time, they were then allowed to cool. The heat treatment resulted in a decrease in the corrosion resistance of the samples, according to the test findings. The surface area roughness of corroded samples increased [18].

The current program's purpose is to investigate and analyze corrosion failures of seamless carbon steel boiler pipes of grade B - 02 utilizing various corroding solutions with varying $\mathrm{pH}$ values.

\section{EXPERIMENTAL PROCEDURE}

Weight loss methodology was used to quantify weight loss or corrosion amounts within the experimental work testing (m.p.y). The explanations of specimen microstructures were also investigated.

Surfaces of corroded samples on the boiler pipe material's water lateral and hot lateral were graphed microscopically, as well as the details that contributed to failure due to corrosion were investigated. Surfaces of corroded samples on the boiler pipe material's water lateral and hot lateral were graphed microscopically, as well as the details that contributed to failure due to corrosion were investigated.

To conclude and explore the corrosion mechanism of similar pipe, the specimens were cut from the cold side lateral of a boiler carbon steel pipe, a material with a density of (7.87 $\left.\mathrm{g} / \mathrm{m}^{3}\right)$ and dimensions $(50 * 50 * 7)$ millimeters according to ASTM G-31 were wet cut [19]. Table 1. Lists chemical composition of the specimens used and the standard composition as defined by ASTM [19].

Before each test, the specimens were cleaned with filtered water to eliminate any pollutants stuck to their surfaces, then soaked in methanol for five minutes before being dried with acetone. Table 1. Shows the carbon steel boiler composition of boiler pipes tubes as evaluated using turbo XRF analyzer.

Table 2 lists numerous corrosive media with varied $\mathrm{pH}$ values that were used to examine corrosion behavior.

Table 3 shows the micro hardness levels measured using Otto Wolpert-Werke V-Tester 2 (GMBH) hardness tester throughout the pipe wall.

Table 4 depicts the weight loss recorded over time as a result of corrosion.

Table 5 depicts the corrosion rate recorded over time as a result of corrosion.

Before each test, each specimen was weighed with a digitally sensitive measuring device to $0.1 \mathrm{mg}$, then the original weight was recorded.

After that, test samples were submerged in a liquid's corrosive media for $(2,4,6,8)$ weeks

Table 1. The carbon steel boiler composition of boiler pipes

\begin{tabular}{cccccccccccc}
\hline Wt., \% & $\boldsymbol{C}$ & $\boldsymbol{M n}$ & $\boldsymbol{P}$ & $\boldsymbol{S i}$ & $\boldsymbol{C r}$ & $\boldsymbol{C u}$ & $\boldsymbol{M o}$ & $\boldsymbol{F e}$ & $\begin{array}{c}\text { Yield Stress, } \\
\boldsymbol{M p a}\end{array}$ & $\begin{array}{c}\text { Ultimate tensile strength, } \\
\boldsymbol{M p a}\end{array}$ \\
\hline Standard value [20] & 0.39 & $0.29-1.06$ & 0.035 & 0.1 & 0.4 & 0.4 & 0.15 & Rem. & 240 & 415 \\
Actual value & 0.29 & 0.55 & 0.01 & 0.32 & 0.38 & 0.02 & 0.09 & 98.34 & 243 & 420 \\
\hline Wt., percent composition of seamless carbon steel boiler pipe as defined by & ASTM [20]. & & & & &
\end{tabular}

Table 2. The results of chemical analyses for cold usage steel

\begin{tabular}{|c|c|c|c|c|c|c|c|c|c|}
\hline No. & PH & $\begin{array}{c}\text { Calcium } \\
\mathrm{Ca}^{+2} \\
(\mathrm{mg} / \mathrm{l}) \\
\end{array}$ & $\begin{array}{c}\text { Nitrate } \\
\operatorname{No3}^{-1}(m g / l)\end{array}$ & $\begin{array}{l}\text { Chloride } \\
\mathrm{Cl}^{-1}(\mathrm{mg} / \mathrm{l})\end{array}$ & $\begin{array}{l}\text { Fluoride F } \\
\quad(m g / l)\end{array}$ & $\begin{array}{l}\text { Magnesium } \\
\operatorname{Mg}^{+2}(m g / l)\end{array}$ & $\begin{array}{c}\text { Sulfate } \\
\operatorname{SO}^{-2}(m g / l)\end{array}$ & $\begin{array}{c}\text { Corrosive } \\
\text { hardness } \\
\mathrm{CaCO}_{3}\end{array}$ & $\begin{array}{c}\text { Es Ns/cm } \\
\text { at } 25 \mathrm{c}^{\mathrm{0}}\end{array}$ \\
\hline Model-1 & 7.3 & 51.3 & 0.6 & 26 & 1.15 & 9.4 & 48 & 170 & 422 \\
\hline Model-2 & 7.65 & 10 & 0.2 & 18 & 0.2 & 19.5 & 65 & 145 & 441 \\
\hline Model-3 & 7.9 & 54 & 0.35 & 11 & 1.1 & 17 & 56 & 225 & 421 \\
\hline Model-4 & 7.93 & 38 & 0.31 & 10 & 0.2 & 19.5 & 54 & 230 & 394 \\
\hline Model-5 & 8.1 & 16.0 & 0.33 & 10 & 0.2 & 5.55 & 71 & 270 & 438 \\
\hline Model-6 & 8.4 & 15 & 0.11 & 10 & 0.2 & 17 & 57 & 50 & 418 \\
\hline
\end{tabular}

Table 3. Displays micro hardness Vickers with tensile strength findings

\begin{tabular}{cccc}
\hline Model & Micro hardness Vickers & Yield Stress, $\boldsymbol{M P a}$ & Tensile Stress $\boldsymbol{M P a}$ \\
\hline Fire side tube & 132 & 189 & 382 \\
Central of tube & 142 & 207 & 424 \\
Water side tube & 146 & 219 & 429 \\
\hline
\end{tabular}


Table 4. Weight loss of specimens over time due to corrosion

\begin{tabular}{cccccc}
\hline \multicolumn{6}{c}{ Corrosion period, Week } \\
\hline NO. & 2 & 4 & 6 & 8 \\
Weight, mgrs. \\
\hline Model-1 & 50.43 & 84.5 & 121.5 & 158.4 & 189.2 \\
Model-2 & 48.38 & 80.4 & 115.3 & 150.6 & 179.0 \\
Model-3 & 46.43 & 76.5 & 109.3 & 140.4 & 169.25 \\
Model-4 & 43.99 & 73.9 & 106.8 & 135.8 & 160.96 \\
Model-5 & 43.50 & 73.6 & 103.3 & 134.2 & 159.0 \\
Model-6 & 40.77 & 65.7 & 93.0 & 121.8 & 144.37 \\
\hline
\end{tabular}

Table 5. Specimens wear rates for different corrosion

\begin{tabular}{cccccc}
\hline \multicolumn{6}{c}{ Corrosion period, Week } \\
\hline NO. & 2 & 4 & 6 & 8 & 10 \\
\hline \multicolumn{5}{c}{ Corrosion rate, mpy } \\
\hline Model-1 & 4.4 & 4.51 & 4.76 & 4.96 & 5.17 \\
Model-2 & 3.77 & 3.83 & 3.92 & 4.12 & 4.33 \\
Model-3 & 3.53 & 3.59 & 3.74 & 3.94 & 4.15 \\
Model-4 & 3.4 & 3.48 & 3.65 & 3.86 & 4.06 \\
Model-5 & 3.26 & 3.33 & 3.47 & 3.67 & 3.88 \\
Model-6 & 4.4 & 4.51 & 4.76 & 4.96 & 5.17
\end{tabular}

The specimens were removed from the corrosive liquid at the conclusion of each test, gutted with Clarke's solution (100HCl, 2 parts sb203, 5 parts $\mathrm{SnC}_{12}$ ) [21], and processed through a Schneller Schally apparatus for one minute before being dried using a drier machine.

The average corrosion rate (mpy) was then enumerated using the formula $[21,22]$.

$$
\begin{gathered}
\text { mpy }=(534 * w) /(\rho * A * t) \\
\text { mpy }=\text { mils per year } ;=\text { lost weight, } \mathrm{mgr} ; \\
\rho=\text { material density, } \mathrm{gr} / \mathrm{cm}^{3} ; \\
A=\text { surface area, } \mathrm{cm}^{2} ; \\
t=\text { exposure duration in hours }
\end{gathered}
$$

Figures 13 to 15 displayed the weight loss against time in contact with corrosive media and the degradation amount vs time curves.

The oxidized surfaces that resulted from corrosion were photographed using a Zeiss Stereo microscope to demonstrate the impact of the corrosive media on the material's cold sides surfaces.

\section{RESULT AND DISCUSSION}

Figure 1 depicts a cross-sectional carbon steel microstructure pipe (A106 grads B-2 ASTM) sample.

The microstructure shown in Figure 1 was obtained after thermal treating process of the distorted samples in accordance with ASTM standards.

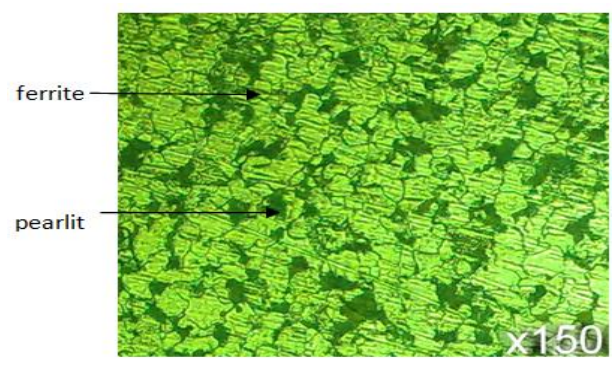

Figure 1. Ferrite and pearlite phases in carbon steel pipe
Figure 2 depicts a brand-new boiler pipe cross section with plainly visible rusted areas on the pipe's inner side.

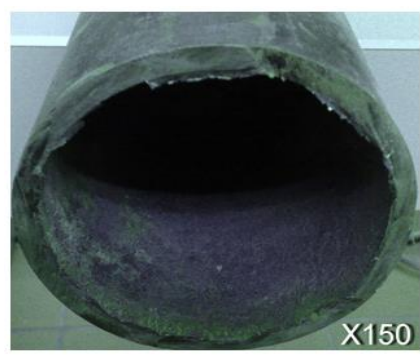

Figure 2. Brand-new seamless carbon steel pipe

Water-side surface boiler pipes were coated after fabrication to prevent corrosion, but due to improper usage, some pipe areas missed their covering layer as depicted in Figure 3, which could be considered areas where corrosion began and advanced, as can be seen in Figure 4, where it appears to be a corroded surface of a cold side cross sectional pipe.
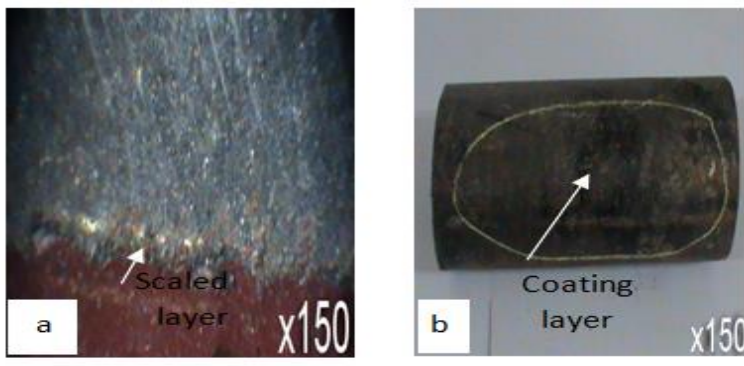

Figure 3. Macrograph viewing surface scales on the water side of seamless carbon steel pipe

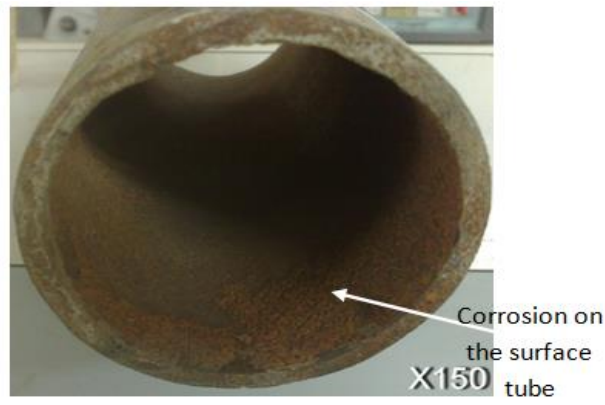

Figure 4. Water corrosion on the inside surface of carbon steel Pipe

Figure 5 depicts a photomicrograph of a water-side microstructure with a ferritic phase and pearlite microstructure.

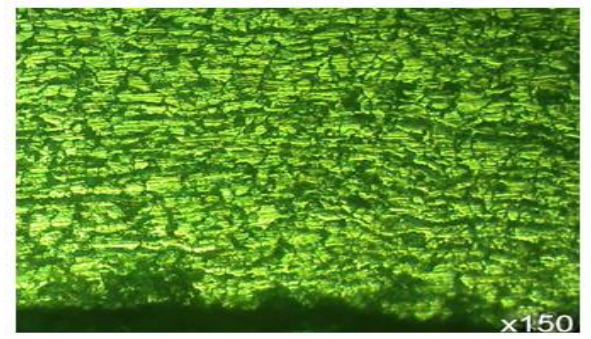

Figure 5. Internal surface of carbon steel pipe with a microstructure on the water side 
Figure 6 depicts a microstructure on the fire side of an express section. On the fire side of the boiler pipe, a decarburized zone of approximately $240 \mathrm{~m}$ thickness containing a phase of few pearlites plus ferrite microstructure has formed, as shown in the figure.

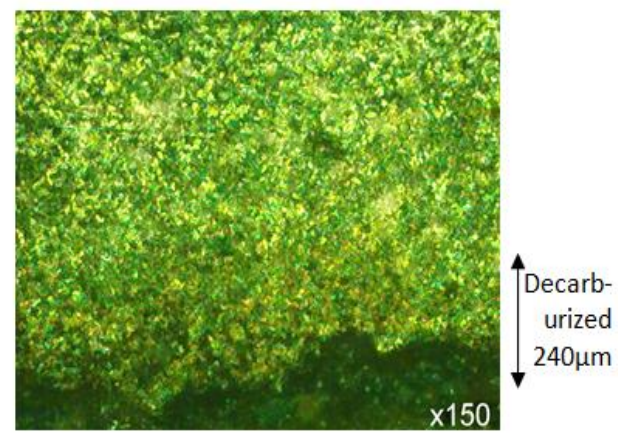

Figure 6. Decarburized layer on the fire side surface of carbon steel pipe

Figure 7 shows scaling corrosion on the water side as a result of high temperatures and water pressure.

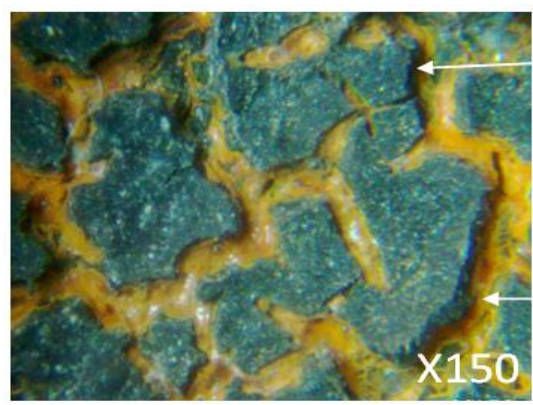

Scale

Rust

Figure 7. Water-side climbing corrosion of carbon steel pipe

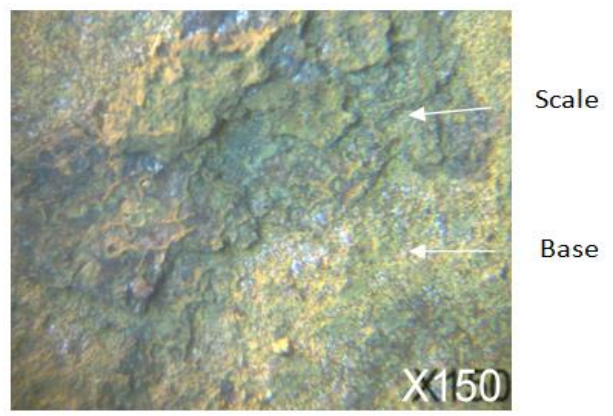

Figure 8. Scaling of carbon steel pipe and disconnected scale regions

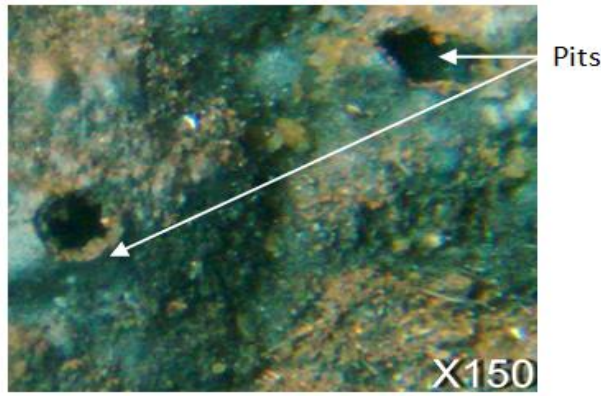

Figure 9. Water-side pitting corrosion of carbon steel pipe
Corrosion has resulted in the formation of a large surface oxidized zone with a diversity scale, as shown in Figure. 8. They have become larger, broken and separated from the surface.

Pitting corrosion occurs as a result of high temperatures and the contact of exhaust fuels with the water side surface, as seen in Figure 9.

Corrosion pitting happens in metals with a protective barrier, like as corrosive chemicals, or if a protective film deteriorates. When the exposed portion surface gives up electrons quickly, the reaction begins small pits with contained reactivity, allowing for fast cracking.

The presence of dissolved oxygen in water can result in brown spots of iron oxide and iron hydroxide.

Because there is an excess of oxygen in the water, it interacts with iron hydroxide.

$$
4 \mathrm{Fe}(\mathrm{oH}) 2+\mathrm{O} 2=2 \mathrm{H} 2 \mathrm{O}+2 \mathrm{Fe} \mathrm{O} 3 . \mathrm{H} 2 \mathrm{O}
$$

Hydrated iron oxide (brown rust) + iron hydroxide

$$
+ \text { oxygen }+ \text { water. }
$$

As demonstrated in Figure 10, this might result in the development and precipitation of brown oxidize on the pipe surface.

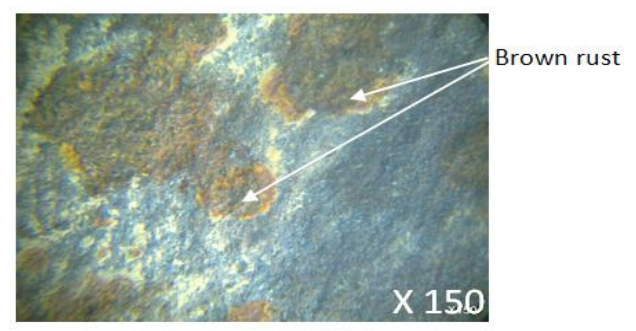

Figure 10. Pitting corrosion with brown rust patches that is large and deep

As a result of the brown oxidizes growing in size and covering a large area of the water side surface pipe, and detaching from the pipe surface, pitting due to corrosion develops as seen in Figure 11 (A, B, C, D).

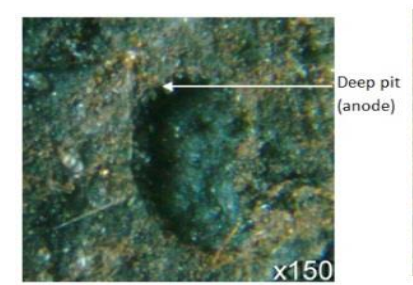

A)

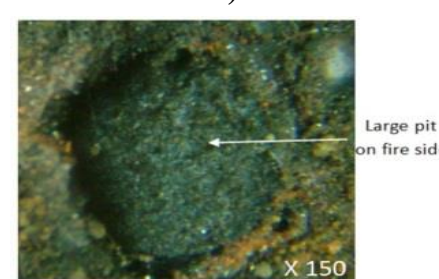

C)

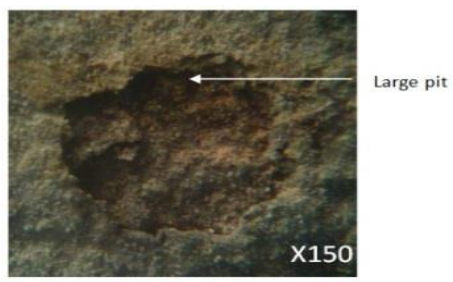

B)

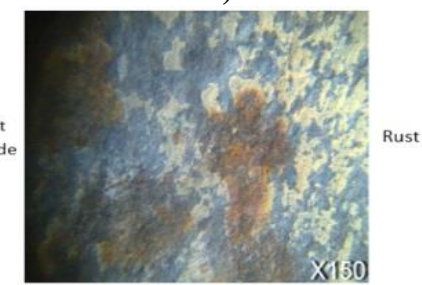

D)
Figure 11. Pitting on the surfaces of carbon steel pipes A- Carbon steel pipe with deep pitting on the fire side B- Pitting with significant depths

C- Significant pitting of carbon steel pipe

D- Carbon steel pipe pitting due to corrosion rust 
Pitting on the seamless carbon steel pipe surfaces (Figure 11). A-Deep pitting of seamless carbon steel boiler pipe on the fire side B-Pitting with a lot of depth C-Boiler with large pitting of seamless carbon steel pipe D-Corrosion rusting on seamless carbon steel boiler pipe. Because of the intensity pits existence, and floor layer pipe scales, and a decrease in $\mathrm{PH}$ value, the ones pits, as well as scales grew larger, as proven in Figure 12.

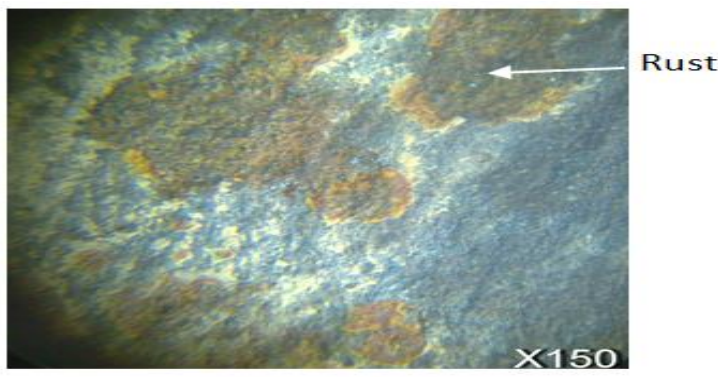

Figure 12. Carbon steel surface pipe with deep and wide depths

For varied $\mathrm{PH}$ values and corrosive hardness $\left(\mathrm{CaCO}_{3}\right)$, Figure 13 shows the difference in lost weight in relation to the duration of exposure to corrosion media. With an increase in exposure time to corrosive medium, the figure shows an increase in weight loss.

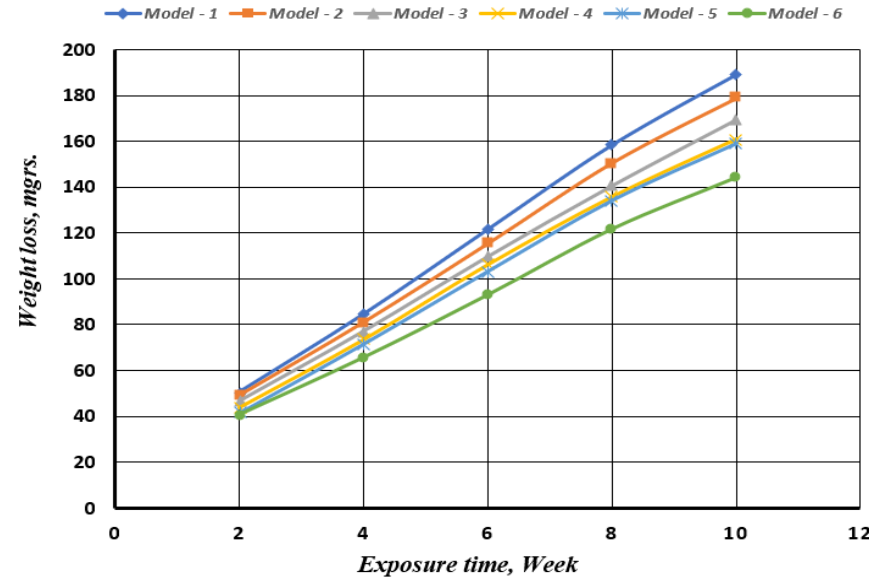

Figure 13. Depicts the weight loss of carbon steel pipe specimens as a function of exposure time to corrosion fluid at various $\mathrm{pH}$ levels

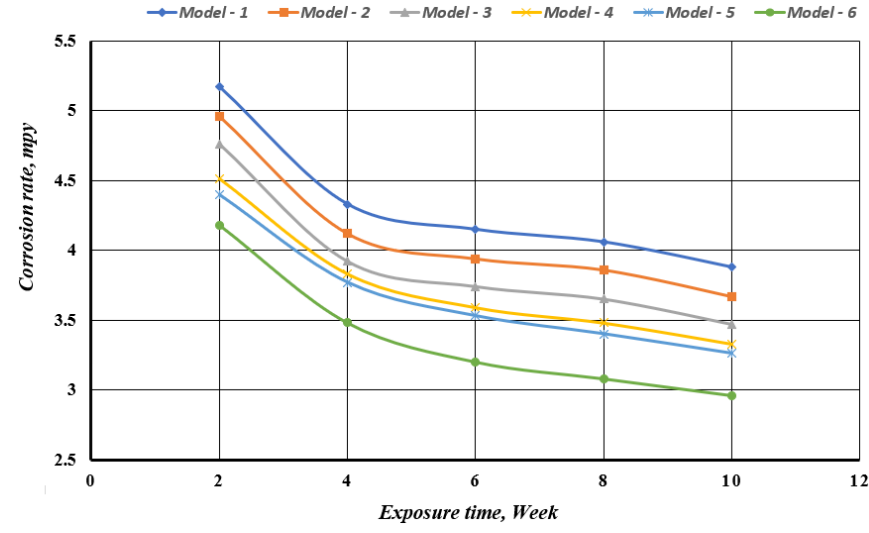

Figure 14. Corrosion rate of carbon steel pipe specimens vs. time exposed to corrosion media at varied $\mathrm{pH}$ values
For varied $\mathrm{pH}$ and hardness values, Figure 14 depicts the difference in corrosion amount (mpy) as a function of exposure time to corrosive media.

The corrosion of boiler pipe material has been reduced when the $\mathrm{pH}$ value has increased from 7.2 to 8.4 , as shown in Figure 14 and Figure 15.

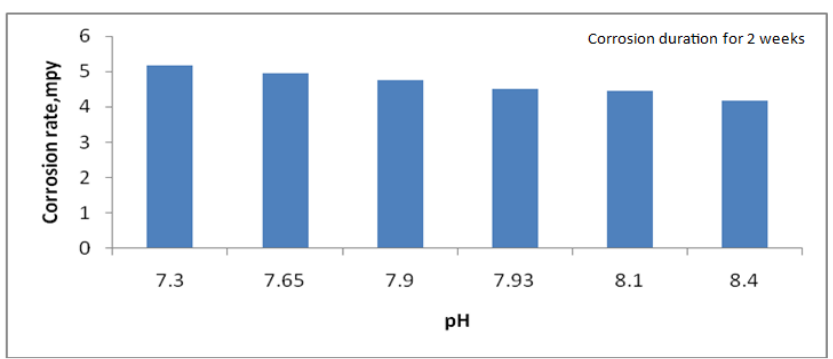

Figure 15. Corrosion rate of steel tube sample in relation to $\mathrm{pH}$ value

The corrosive impact of low $\mathrm{pH}$ water caused the corrosion rate to decrease. The solubility of calcium carbonate decreased as the $\mathrm{pH}$ value increased, making it more likely to precipitate in the form of flakes, while high alkalinity water led to the production of flakes at lower $\mathrm{pH}$ values.

The development of oxidation in corroded samples is illustrated in Figure 16A, which shows that small sizes with low amounts of oxidation formed in the surface layers at low $\mathrm{pH}$ values, but their size and quantity grew substantially at $\mathrm{pH}$ values elevated. as shown in Figure 16 B.

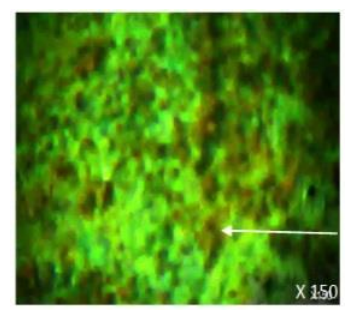

A)

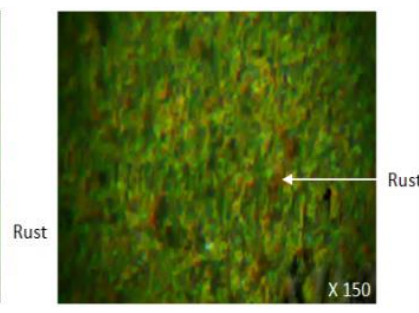

B)
Figure 16. Corrosion oxides on carbon steel pipe surfaces

\section{CONCLUSIONS}

The following findings were reached after studying corrosion failure and corrosion behavior of seamless carbon steel ASTM106 grad B boiler tubes with the aid of the use of corrosive media with various $\mathrm{pH}$ values for various corrosion duration:

1. Minimum weight losses were identified after 10 weeks of testing, whereas maximum corrosion rates were discovered at two weeks of testing.

2. Corrosion rates for steel increase as chloride ion concentration rises.

3. Owing to the forming and manufacturing processes, the grains of carbon steel boiler tubes were distorted and elongated, which quickens the corrosion process due to the interior tensions that were produced inside those grains.

4. The fire side of a tube was lined with ferritic microstructure with a decarburized layers of $240 \mu \mathrm{m}$ thickness were produced. 
5. Contact of the exhaust fuel with the water caused pitting due to corrosion on the top layer of the cold side pipe.

6. The corrosion-induced lost weight of carbon steel pipe specimens increased as the period of exposure to corrosive environments were increased.

7. The corrosion rates of carbon steel pipe samples were reduced when the period of exposure to corrosive environments was increased.

8. The rate of corrosion of the specimens was reduced when the $\mathrm{pH}$ value was raised.

9. At a low $\mathrm{pH}$ value, little rust was discovered on the corroded surface of the seamless carbon steel boiler tube specimen.

10. On the corroded carbon steel boiler tube specimen with a high $\mathrm{pH}$ value, big scale rust was discovered.

\section{ACKNOWLEDGMENT}

This research was supported by the Engineering Research Program through the Northern Technical University, funded by the Ministry of Higher Education and Research / Republic of Iraq. (No. 00101 - 2019).

\section{REFERENCES}

[1] Malik, A.U., Andijani, I., Mobin, M., Al-Muaili, F., AlHajri, M. (2017). Corrosion of boiler pipes some case studies saline water Desalination Research Institute. $4^{\text {th }}$ SWCC Acquired Experience Symposium Held at Jeddah, pp. 739-763.

[2] Lobely, G.R., Al-Qtaibi, W.L. (2008). Diagnosing boiler tube failure related to overheating. Advanced Materials Research, 41-42:

175-181. https://doi.org/10.4028/www.scientific.net/AMR.4142.175

[3] Roberge, P.R. (2008). Corrosion Engineering Principles and Practice. McGraw-Hill Companies, Inc.

[4] Luo, X., Zhang. Z. (2013). Leakage failure analysis in a power plant boiler. IERI Procedia, 5: 107-111. https://doi.org/10.1016/j.ieri.2013.11.078

[5] Liu, S.W., Wang, W.Z., Liu, C.J. (2017). Failure analysis of the boiler water-wall tube. Case Studies in Engineering Failure Analysis, 9: 35-39. https://doi.org/10.1016/j.csefa.2017.06.002

[6] Huang, X., Sun, M., Kang, Y. (2019). Fireside corrosion on heat exchanger surfaces and its effect on the performance of gas-fired instantaneous water heaters. Energies, $12(13)$ : 2583. https://doi.org/10.3390/en12132583

[7] Gupta, G.K., Chattopadhyaya, S. (2017). Critical failure analysis of superheater tubes of coal-based boiler. Journal of Mechanical Engineering, 63(5): 287-299. https://doi.org/10.5545/sv-jme.2016.4188

[8] Ardya, H., Putra, Y.P., Anggoro, A.D., Wibowoa, A. (2021). Failure analysis of primary waste heat boiler tube in ammonia plan. Heliyon, 7(2): 1-11. https://doi.org/10.1016/j.heliyon.2021.e06151

[9] Asnavandi, M., Kahram, M., Rezaei, M,, Rezakhani, R. (2017). Fire-side corrosion: A case study of failed tubes of a fossil fuel boiler. International Journal of Corrosion, 2017: 1-8. https://doi.org/10.1155/2017/7367046

[10] Moakhar, R.S., Mehdipour, M., Ghorbani, M., Mohebali, M., Koohbor, B. (2013). Investigations of the failure in boilers economizer tubes used in power plants. Journal of Materials Engineering and Performance, 22: 26912697. https://doi.org/10.1007/s11665-013-0567-2

[11] Kumar, A., Sapra, P.K. (2013). Boiler tubes failure: Causes and remedies a case study of a fertilizer plant. International Journal on Emerging Technologies, 4(2): 132-135.

[12] Roy, B.N., Kumar, S., Oraon, S., Soren, R. (2017). Study of high temperature corrosion on boiler tube material. International Journal of Trend in Research and Development, 4(1): 619-621.

[13] Kumari, A., Das, S.K., Srivastava, P.K. (2015). Impact of boiler water chemistry on waterside tube failures. IJIRST -International Journal for Innovative Research in Science \& Technology, 2(4): 28-35.

[14] Choi, Y.S., Nešić, S., Jung, H.G. (2018). Effect of alloying elements on the corrosion behavior of carbon steel in $\mathrm{CO}_{2}$ environments. Corrosion, 74(5): 566-576. https://doi.org/10.5006/2705

[15] Kim, Y.S., Kim, J.G. (2017). Corrosion behavior of pipeline carbon steel under different iron oxide deposits in the district heating system. Metals, 7(5): 182. https://doi.org/10.3390/met7050182

[16] Panossian, Z., de Almeida, N.L., de Sousa, R.M.F., de Souza Pimenta, G., Marques, L.N.S. (2012). Corrosion of carbon steel pipes and tanks by concentrated sulfuric acid: A review. Corrosion Science, 58: 1-11. https://doi.org/10.1016/j.corsci.2012.01.025

[17] Yin, Z.F., Feng, Y.R., Zhao, W.Z., Bai, Z.Q., Lin, G.F. (2009). Effect of temperature on $\mathrm{CO}_{2}$ corrosion of carbon steel. Surface Interface Analysis, 41(6): 517-523. https://doi.org/10.1002/sia.3057

[18] Hamid, K.L., Moustafa, N.M., Noori, A.F. (2020). Heat treatment effect on carbon steel corrosion resistance at different carbon content. Journal of Mechanical Engineering Research and Developments, 43(5): 231237.

[19] Standard Specification for Seamless Carbon Steel Pipe for High Temperature Service. (2007). ASTM international Designation: A106/A106 M-04, pp. 1-8.

[20] An American National Standard used in USDOE-NE standard.

[21] Owate, I.O., Ezi, C.W.I., Avwiri, G. (2002). Impact of environmental conditions on sub-surface storage tanks (Part I). Journal of Applied Sciences \& Environmental Management, $6(2)$ : 79-83. https://doi.org/10.4314/jasem.v6i2.17182

[22] Corrosion Tests and Standards application and interpretation. 2NDEition.Robert Babayan Editor. (2005). MNL20-2 $2^{\text {nd }}-$ EB/Jan. 